\title{
Protodioscin levels in Brachiaria spp. in a sheep production system and a brief review of the literature of Brachiaria spp. poisoning in ruminants ${ }^{1}$
}

\author{
Alberto 0. Gaspar ${ }^{2}$ (D), Carolina C. Guizelini ${ }^{3}$ (D), Francisca C. Roberto ${ }^{4}$, \\ Gelson S. Difante ${ }^{5}$, Ricardo C. Brumatti ${ }^{5}$, Camila C.B.F Ítavo ${ }^{5}$, \\ Ricardo A.A. Lemos ${ }^{5 *}$ (D) and Stephen T. Lee ${ }^{6}$
}

\begin{abstract}
Gaspar A.O., Guizelini C.C., Roberto F.C., Difante G.S., Brumatti R.C., Ítavo C.C.B.F., Lemos R.A.A. \& Lee S.T. 2021. Protodioscin levels in Brachiaria spp. in a sheep production system and a brief review of the literature of Brachiaria spp. poisoning in ruminants. Pesquisa Veterinária Brasileira 41:e06921, 2021. Faculdade de Medicina Veterinária e Zootecnia, Universidade Federal de Mato Grosso do Sul, Av. Senador Felinto Muller 2443, Campo Grande, MS 79070-900, Brazil.E-mail: ricardo.lemos@ufms.br

Plants of the genus Brachiaria, used in several countries as forage, are poisonous to some livestock species. Their toxic principle is protodioscin, and the main form of clinical presentation of the toxicosis is hepatogenous photosensitization. Here we compare protodioscin levels in B. decumbens and B. brizantha and review the literature on the concentrations and methodologies of collection and analysis of the toxic principle in Brachiaria spp. and the risk of contamination of pastures by more toxic species that may facilitate poisoning by plants of this genus in sheep. The experiment was conducted in pastures originally formed by $B$. brizantha, with many $B$. decumbens invasion points. The occurrence of cases of poisoning by Brachiaria spp. was the criterion for confirming pasture toxicity. The forage samples were collected at ten random points every 28 days through manual grazing simulation. The samples were analyzed for protodioscin by high-performance liquid chromatography (HPLC) with light scattering by evaporation (ELSD) after being dried and crushed. In the flock of 69 sheep, five poisoning cases occurred, three sheep died, and two recovered. The protodioscin levels found in the evaluated pastures ranged from 0.70 to $0.45 \%$; higher levels appeared in B. decumbens (7.09\%) compared to $1.04 \%$ in B. brizantha. We suggest that Brachiaria spp. should be avoided in pastures where sheep are grazing.
\end{abstract}

INDEX TERMS: Protodioscin levels, Brachiaria spp., sheep, ovine, toxic plants, plant poisoning, ruminants, hepatogenic photosensitization, photodermatitis, tropical pasture, ruminant, steroidal saponins.

\footnotetext{
${ }^{1}$ Received on May 15, 2021.

Accepted for publication on May 28, 2021.

${ }^{2}$ Graduate Program in Animal Science, Faculdade de Medicina Veterinária e Zootecnia (FAMEZ), Universidade Federal de Mato Grosso do Sul (UFMS), Av. Senador Felinto Muller 2443, Campo Grande, MS 79070-900, Brazil.

${ }^{3}$ Graduate Program in Veterinary Science, Faculdade de Medicina Veterinária e Zootecnia (FAMEZ), Universidade Federal de Mato Grosso do Sul (UFMS), Av. Senador Felinto Muller 2443, Campo Grande, MS 79070-900, Brazil.

${ }^{4}$ Integrated Doctoral Program in Animal Science, Centro de Ciências Agrárias, Campus II, Universidade Federal da Paraíba (UFPB), Rodovia PB079, Areia, PB 58397-000, Brazil.

${ }^{5}$ Faculdade de Medicina Veterinária e Zootecnia (FAMEZ), Universidade Federal de Mato Grosso do Sul (UFMS), Av. Senador Felinto Muller 2443, Campo Gr ande, MS 79070-900, Brazil. *Corresponding author: ricardo.lemos@ufms.br

${ }^{6}$ Poisonous Plant Research Laboratory, Agricultural Research Service, United States Department of Agriculture, 1150 E. 1400 N., Logan, UT 84341, USA.
}

RESUMO.- [Níveis de protodioscina em Brachiaria spp. em um sistema de produção de ovinos e uma breve revisão da literatura da intoxicação por Brachiaria spp. em ruminantes.] Plantas do gênero Brachiaria, utilizadas em vários países como forragem, são tóxicas para várias espécies pecuárias. Seu princípio tóxico é a protodioscina, e a principal forma de apresentação clínica da toxicose é a fotossensibilização hepatógena. Este estudo teve como objetivo comparar os níveis de protodioscina em $B$. decumbens e $B$. brizantha e revisar a literatura sobre as concentrações e metodologias de coleta e análise do princípio tóxico em Brachiaria spp. e o risco de contaminação das pastagens por espécies mais tóxicas que podem facilitar a intoxicação por plantas desse gênero em ovinos. 0 experimento foi conduzido em pastagens originalmente formadas por $B$. brizantha, com 
diversos pontos de invasão por $B$. decumbens. Ocorrência de casos de intoxicação por Brachiaria spp. foi o critério para confirmação da toxicidade da pastagem. As amostras de forragem foram coletadas a cada 28 dias em dez pontos aleatórios por meio de simulação de pastejo manual. As amostras foram analisadas para protodioscina por cromatografia líquida de alta eficiência (HPLC) com dispersão de luz por evaporação (ELSD) após serem secadas e trituradas. No rebanho de 69 ovelhas, cinco desenvolveram a intoxicação, três morreram e duas se recuperaram. Os níveis de protodioscina encontrados nas pastagens avaliadas variaram de 0,70 a $0,45 \%$; níveis mais elevados apareceram em $B$. decumbens (7,09\%) em comparação com 1,04\% em B. brizantha. Sugerimos que Brachiaria spp. deve ser evitada no pasto de ovelhas em pastejo.

TERMOS DE INDEXAÇÃO: Protodioscina, Brachiaria spp., ovinos, intoxicação por plantas, ruminantes, fotossensibilização hepatógena, fotodermatite, pastagem tropical, ruminante, saponinas esteroidais.

\section{INTRODUCTION}

Plants of the genus Brachiaria are used in several countries as forage (Muniandy et al. 2020) and cause spontaneous poisoning in cattle (Souza et al. 2010, Riet-Correa et al. 2011), sheep (Riet-Correa et al. 2011, Faccin et al. 2014, Melo et al. 2018, 2019a), goats (Rosa et al. 2016), buffaloes (De Oliveira et al. 2013), and horses (Barbosa et al. 2006). The poisoning was reproduced in sheep (Cruz et al. 2001, Driemeier et al. 2002, Saturnino et al. 2010, Porto et al. 2013), and rabbits (Utiumi et al. 2018). The main clinical presentation of the toxicosis in all livestock species is hepatogenous photosensitization (RietCorrea et al. 2011, Collett 2019). However, other syndromes are also associated with Brachiaria toxicosis, such as progressive weight loss and neurological disorders (Muniandy et al. 2020).

The main toxic principle in Brachiaria spp. is protodioscin, which is present in higher concentrations in B. decumbens and in lower concentrations in the other cultivars of Brachiaria (Low 2015, Lozano et al. 2017). However, the lack of standardization in the methodology for collecting forage samples for analysis makes it difficult to compare these concentrations and determine the toxic principle levels (Melo et al. 2018). In addition to protodioscin levels in the pasture, other factors, such as the adaptation of animals (Faccin et al. 2014, Castro et al. 2018), age (Riet-Correa et al. 2011, Muniandy et al. 2020), genetic resistance (Pupin et al. 2016), and animal species involved (Riet-Correa et al. 2011, Lozano et al. 2017), affect the occurrence of poisoning.

Although various studies demonstrate that several species of Brachiaria induce poisoning, in some outbreaks, the sum of the ingestion of different species of Brachiaria spp. is responsible for the poisoning (Souza et al. 2010, Ogliari et al. 2018). In those instances, the protodioscin concentrations were not determined (Lemos et al. 1996, Caicedo et al. 2012, Rosa et al. 2016, Utiumi et al. 2018), and even when they were, each plant species was not analyzed separately (Mustafa et al. 2012, Diamantino et al. 2018, Melo et al. 2018, 2019a, 2019b).

The main objective of this study was to evaluate the levels of protodioscin in B. decumbens and B. brizantha in pastures where Brachiaria poisoning in sheep occurred. We also review the literature on the concentrations and methodologies of sampling of the plant and analysis of the toxic principle and evaluate the risk of infestation of the pastures by more toxic plant species, in facilitating the occurrence of poisoning by plants of this genus in ruminants.

\section{MATERIALS AND METHODS}

The study was approved by the Ethics Committee on the Use of Animals of the "Universidade Federal de Mato Grosso do Sul" (UFMS), protocol number 0862/2017.

The experiment was carried out within the experimental area of the "Fazenda Escola" of the UFMS $\left(20^{\circ} 26^{\prime} 34.31^{\prime}\right.$ "South and $54^{\circ} 50^{\prime} 27.86^{\prime \prime}$ West, $530.7 \mathrm{~m}$ altitude) from November 2018 to April 2019. The region is a rainy tropical savanna, subtype Aw, with seasonal rainfall distribution. The experimental period was in the most significant annual rainfall period, with an average temperature of $25.4^{\circ} \mathrm{C}$ and an accumulated rainfall of $829.7 \mathrm{~mm}$ (INMET 2018).

Brachiaria brizantha originally formed the pastures, which were later invaded by many spots of Brachiaria decumbens. These pastures were occupied in previous years by sheep that developed poisoning with Brachiaria spp. (Pupin et al. 2016, Melo et al. 2018, 2019a). The grazing areas had drinking fountains and a small covered area with free access for night shelter and protection against eventual rainfalls or intense sunlight exposure.

The flock was initially composed of 69 lambs born to fathers and mothers adapted to the consumption of pastures formed by the Brachiaria spp. The criterion used to consider an adapted or resistant sheep was the absence of clinical signs throughout its lifespan, even when kept in pastures made up exclusively of Brachiaria spp. (Gracindo et al. 2014, Pupin et al. 2016, Melo et al. 2019a). The ram breeder of the herd was supposedly adapted. However, it has a family history of illness and death due to Brachiaria spp. poisoning.

The grazing method lambs were managed with continuous stocking and variable stocking rate, supplemented daily with mineral supplement and energy protein supplement. The sheep were identified with earrings and necklaces and dewormed with $1 \mathrm{ml} / 10 \mathrm{~kg}$ of oral closantel 10 days before the beginning of the experiment.

The sheep were observed daily for clinical signs described for Brachiaria spp. poisoning. These include edema, erythema, and crusts in the non-pigmented areas of the face and ears, apathy, anorexia, and jaundice (Mustafa et al. 2012, Porto et al. 2013, Faccin et al. 2014, Pupin et al. 2016, Melo et al. 2018, 2019a). When those signs were spotted in any lamb, it underwent thorough clinical examinations and immediately removed from the lot, kept in stalls sheltered from sunlight, consuming mineral salt, energy-based protein concentrate soybean meal, and crushed corn fresh millet and water ad libitum. In fatal cases, a necropsy was performed, and fragments of several organs were collected in 10\% formalin solution for histopathological processing routine staining by the hematoxylin and eosin (HE) technique. The occurrence of poisoning cases by Brachiaria spp. was a criterion for confirming pasture toxicity.

Five Brachiaria samples were collected from the paddocks at intervals of every 28 days by manual grazing simulation (Cook 1964). Before sampling, we observed the sheep grazing behavior location and forage proportion, with an average of ten different locations in each paddock, to obtain a sample of the plant similar to that selected by the lambs. Samples were also collected from the mixed pasture of Brachiaria spp. (cv. Maranda and cv. Basilisk) and samples of each cultivar.

After collection, the samples were weighed and dried at $55^{\circ} \mathrm{C}$ for $72 \mathrm{~h}$, ground in a mill with a 1-mm sieve screen, and stored. They were then analyzed to detect protodioscin using high-performance liquid chromatography-electrospray ionization mass spectrometry (HPLC-ESI-MS), as previously described (Lee et al. 2009). 


\section{RESULTS}

There was a predilection for the sheep to graze areas that contained Brachiaria decumbens over Brachiaria brizantha. After consuming all the grass of their first choice, they then went on to consume $B$. brizantha.

Five sheep got sick, three died, and two recovered. At necropsy of the three sheep, the observed changes were similar and varied only in severity. Jaundice was consistent in the ocular and oral mucosa, subcutaneous tissue, omentum, and arteries' intima. The liver was diffusely yellow-brown with a marked lobular pattern; there was a coppery hue to the kidneys' cortex.

Histologically, there was moderate hyperplasia of the hepatic bile ducts, which had their lumina distended and filled by negative images of birefringent acicular crystals. A minimal lymphocytic infiltration was the periportal regions. In the centrilobular and periportal areas, there were abundant clusters of macrophages with abundant foamy cytoplasm. Occasionally, in the centrilobular regions, individual hepatocellular necrosis was observed. Cholestasis was also a consistent finding.

The levels of protodioscin found in the samples of the evaluated paddocks ranged from 0.70 to $1.45 \%$, and when the species were analyzed separately, higher levels were observed in B. decumbens (7.09\%) than B. brizantha (1.04\%).

The epidemiological data and protodioscin concentrations from previous studies are given in Table 1 and 2.

\section{DISCUSSION}

Pasture toxicity was determined by the occurrence of cases with clinical and pathological features of Brachiaria spp. poisoning (Mustafa et al. 2012, Porto et al. 2013, Faccin et al. 2014, Pupin et al. 2016, Melo et al. 2018, 2019a). The pasture where the sheep were grazing was previously reported as toxic (Faccin et al. 2014, Melo et al. 2019a). However, in these previous reports, only Brachiaria brizantha was considered since the pasture had been formed using seeds of this type of forage. Although it was not possible to quantitatively assess the presence of Brachiaria decumbens, the possibility of contamination of the seeds or even the invasion of pasture by this other species cannot be ruled out in previous outbreaks.

$B$. decumbens in pasture and the preference of sheep for its consumption over B. brizantha, as observed in the current study, shows that the introduction of sheep in paddocks where this forage is present is a high-risk factor for the poisoning. This fact is even more relevant if we consider that the poisoning occurred in a herd consisting of sheep considered resistant to the ill-effects of Brachiaria spp.

The fact that a ram with no history of Brachiaria spp. poisoning can transmit vulnerability to poisoning to their offspring is a limiting factor for selecting resistant herds since the main criterion adopted for this selection is the culling of animals that show clinical signs of poisoning (Faccin et al. 2014). This criterion is efficient in herds with well-defined zootechnical and sanitary standards. However, it does not apply to breeding sheep, mainly when they are from places where forages of Brachiaria are absent from the pastures. Considering that young sheep are more sensitive (Muniandy et al. 2020) and breeders are acquired as adults, the criterion of the absence of clinical signs of poisoning in breeders is not a guarantee of resistance in their offspring.

This study has four key findings: (i) a difference in the concentration of protodioscin between the two Brachiaria species was observed; (ii) sheep show a preference for $B$. decumbens; (iii) the characterization of the composition of the pasture; and (iv) the stratified analysis of the concentrations of the toxic principle in both plant species should be done as standard in cases of outbreaks or studies on the toxicity of Brachiaria spp.

Table 1. Data on several outbreaks of Brachiaria spp. poisoning in ruminants

\begin{tabular}{|c|c|c|c|c|c|c|}
\hline References & Plant species & Animal species & Number of animals & $\begin{array}{l}\text { Age in } \\
\text { months }\end{array}$ & Sick animals & Dead animals \\
\hline Mustafa et al. (2012) & Brachiaria spp. & Sheep & 1305 & $6-12$ & - & 371 \\
\hline Gracindo et al. (2014) & & Sheep & 48 & $<5$ & 2 & 1 \\
\hline Pupin et al. (2016) & & Sheep & 31 & $2-5 s$ & 11 & 4 \\
\hline Castro et al. (2018) & & Sheep & 45 & 4 a 5 & 4 & 3 \\
\hline Ogliari et al. (2018) & & Sheep/Goat & 628 & NI & 27 & 17 \\
\hline Melo et al. (2018) & & Sheep & 68 & $8-48$ & 21 & 5 \\
\hline Melo et al. (2019a) & & Sheep & 13 & $\mathrm{NI}$ & 12 & - \\
\hline Melo et al. (2019b) & & Sheep & 15 & $<3$ & 15 & 4 \\
\hline Present study & & Sheep & 69 & $<6$ & 5 & 3 \\
\hline Lemos et al. (1996) & B. decumbens & Sheep & 120 & $>11 \mathrm{~s}$ & 49 & 30 \\
\hline Brum et al. (2007) & & Sheep & 28 & NI & 8 & 6 \\
\hline Saturnino et al. (2010) & & Sheep & 24 & $<5$ & 11 & 11 \\
\hline Caicedo et al. (2012) & & Cattle & 5 & $42 \mathrm{~s}$ & 5 & - \\
\hline De Oliveira et al. (2013) & & Buffalo & 288 & $3-8$ & 15 & 7 \\
\hline Porto et al. (2013) & & Sheep & 26 & 5 & 4 & 3 \\
\hline Rosa et al. (2016) & & Goat & 1.000 & $\mathrm{NI}$ & 7 & 7 \\
\hline Lelis et al. (2018) & & Sheep & 20 & $\mathrm{NI}$ & 7 & 7 \\
\hline Albernaz et al. (2010) & B. brizantha & Sheep & 49 & $2-3$ & 34 & 31 \\
\hline Faccin et al. (2014) & & Sheep & 38 & $>11$ & 8 & 3 \\
\hline Diamantino et al. (2020) & B. ruziziensis & Sheep & 60 & $3-8$ & 25 & 13 \\
\hline
\end{tabular}


Table 2. Brachiaria spp. poisoning in ruminants. Determination of the levels of protodioscin in the plant and methods of sampling

\begin{tabular}{|c|c|c|c|}
\hline References & Plant species & Method of samplinga & $\begin{array}{c}\text { Levels of } \\
\text { protodioscina }\end{array}$ \\
\hline Mustafa et al. (2012) & Brachiaria spp. & Every 15 days, $2 \mathrm{~cm}$ cuts the soil, ten random locations & $0.3-2.56 \%$ \\
\hline Pupin et al. (2016) & & Every 28 days, simulating grazing & $0.44-1.81 \%$ \\
\hline Diamantino et al. (2018) & & Not informed & $0.71-1.12 \%$ \\
\hline Melo et al. (2018) & & Every 28 days, randomly, with a $0.25 \mathrm{~m}^{2}$ square & $0.3-1.3 \%$ \\
\hline Melo et al. (2019a) & & Metallic square in 10 random points, simulating grazing & $0.42-1.81 \%$ \\
\hline Melo et al. (2019b) & & Ten samples every 28 days, with $0.5 \times 0.5 \mathrm{~m}$ square, close to the ground & $1,04-2.17 \%$ \\
\hline Brum et al. (2007) & B. decumbens & Cuts close to the ground, at 20 points & $1.63-2.36 \%$ \\
\hline Brum et al. (2009) & & At four different stages, cuts at $3 \mathrm{~cm}$ from the soil ${ }^{\mathrm{b}}$ & $0.8-1 ., 9 \%$ \\
\hline De Oliveira et al. (2013) & & Harvest by hand, simulating grazing at random points & $3.24-3.54 \%$ \\
\hline Porto et al. (2013) & & Every 15 days, $2 \mathrm{~cm}$ cuts of soil, 10 random locations & $0.94 \%$ \\
\hline Gracindo et al. (2014) & & Every 15 days, $2 \mathrm{~cm}$ cuts from the ground in 10 points with $1 \mathrm{~m}^{2}$ & $0.33-1.22 \%$ \\
\hline Lozano et al. (2017) & & Collection at three points of $1 \mathrm{~m}^{2}$, simulating grazing & $0.59-2.99 \%$ \\
\hline Castro et al. (2018) & & Air-dried samples every 15 days & $0.62-1.18 \%$ \\
\hline Lelis et al. (2018) & & Six samples every 28 days with a $0.25 \mathrm{~m}^{2}$ metal square, cut at $5 \mathrm{~cm}$ from the ground & $0.9-0.37 \%$ \\
\hline Present study & & Five times during 28 days at 10 different points, simulating grazing & $7.09 \%$ \\
\hline Brum et al. (2009) & B. brizantha & In four different stages, cut $3 \mathrm{~cm}$ from the ground ${ }^{\mathrm{b}}$ & $0.5-2.1 \%$ \\
\hline Ferreira et al. (2011) & & Five weekly leaf collections at different stages of maturation for 60 days & $0.30-4.65 \%$ \\
\hline Lima et al. (2012) & & Fresh plants, dry hay and hay after storage, dried at $65^{\circ} \mathrm{C}$ for 72 hours & $0.86-1.87 \%$ \\
\hline Faccin et al. (2014) & & Young, mature and senescent leaves collected at 10 points every 14 days & $0.87-2.58 \%$ \\
\hline Gracindo et al. (2014) & & Every 15 days, cuts $2 \mathrm{~cm}$ from the ground in 10 points with $1 \mathrm{~m}^{2}$ & $0.28-0.91$ \\
\hline Lozano et al. (2017) & & Collection at three points of $1 \mathrm{~m}^{2}$, simulating grazing & $0.47-1.81 \%$ \\
\hline Castro et al. (2018) & & Air-dried samples every 15 days & $0.74 \%$ \\
\hline Present study & & Five times during 28 days, at 10 different points, simulating grazing & $1.04 \%$ \\
\hline Castro et al. (2018) & B. humidicola & Air-dried samples every 15 days & $0.11 \%$ \\
\hline Diamantino et al. (2020) & B. ruziziensis & Sixty-six collects at three different growth stages: bud, leaves and senescence & $0.004-0.19 \%$ \\
\hline
\end{tabular}

As shown in Table 1, the comparison of protodioscin concentrations in samples of plants of the genus Brachiaria that are toxic to sheep is hampered by the lack of standardization in collecting samples. Although B. decumbens is considered the most toxic among the species (Riet-Correa et al. 2011), its highest concentration of the toxic principle described so far was $3.54 \%$, in the plant's maturation phase (De Oliveira et al. 2013). The vegetative stage has a strong influence on protodioscin concentrations, which are higher in sprouting and decrease as they mature (Castro et al. 2011, Ferreira et al. 2011, Riet-Correa et al. 2011, Lima et al. 2012), as seen in hay samples (Lima et al. 2012, Lozano et al. 2017).

Thus, the collection methodology must consider the animals' feeding habits, as there may be differences in pasture consumption between species. Sheep, for example, have a preference for sprouts and, therefore, it may be that they consume higher levels of the toxic principle (Melo et al. 2019a). In addition to the higher concentrations of protodioscin in B. decumbens compared to B. brizantha (Lima et al. 2012, Lozano et al. 2017), the more significant toxicity of the former is corroborated by the greater numbers of outbreaks caused by $B$. decumbens poisoning, even when the proportion of $B$. brizantha in the pasture is higher (Riet-Correa et al. 2011).

Considering only the analyzes of $B$. decumbens carried out in the present study, the values are higher than those found in all previous evaluations of this and other Brachiaria species, even using different collection methodologies, indicating that this species is responsible for the cases of Brachiaria poisoning in the sheep of the current study. A relevant fact is that in a study carried out in the same area of the present study and using a similar sampling methodology, without considering the invasion by $B$. decumbens, protodioscin levels ranged from $0.42 \%$ to $1.81 \%$ (Melo et al. 2019a). These results, added to the sheep's predilection for consuming this plant, show that one should not use the forage to feed sheep even when mixed with another forage.

It is noteworthy that the presence of protodioscin concentrations is not the only risk factor for poisoning. Another critical risk factor to be considered is the introduction of a breeder with a family history of the occurrence of poisoning. Previous studies have demonstrated the importance of genetics for sensitivity and resistance to poisoning (Pupin et al. 2016) and the higher occurrence of resistant lambs born to a particular breeder, who during his lifetime did not show signs of poisoning (Melo et al. 2018).

\section{CONCLUSIONS}

The concentrations of protodioscin in Brachiaria decumbens may be much higher than the levels considered to be a risk for the occurrence of poisoning in sheep.

The difference between the concentrations of protodioscin observed in B. decumbens and Brachiaria brizantha in the pasture, and the preference of the sheep for the first indicates that the methods for the analysis of the toxic principle in Brachiaria spp. in studies of the toxicity and must include botanical identification and separately chemical species analysis. 
Acknowledgments.- Three of the authors (R.A.A. Lemos, G.S. Difante and C.C.B.F Ítavo) have research fellowships from the "Conselho Nacional de Desenvolvimento Científico e Tecnológico" (CNPq). This work was carried out with the support of the "Coordenação de Aperfeiçoamento de Pessoa de Nível Superior" (CAPES), Brazil - Financing Code 001. The authors were supported by the "Universidade Federal de Mato Grosso do Sul" (UFMS) and "Fundação para o Desenvolvimento da Educação, Ciência e Tecnologia do Estado do Mato Grosso do Sul" (FUNDECT).

Conflict of interest statement.- The authors declare no conflict of interest.

\section{REFERENCES}

Albernaz T.T., Silveira J.A.S., Silva N.S., Oliveira C.H.S., Reis A.S.B., Oliveira C.M.C., Duarte M.D. \& Barbosa J.D. 2010. Fotossensibilização em ovinos associada à ingestão de Brachiaria brizantha no estado do Pará. Pesq. Vet. Bras. 30(9):741-748.<https://dx.doi.org/10.1590/S0100-736X2010000900006>

Barbosa J.D., Oliveira C.M.C., Tokarnia C.H. \& Peixoto P.V. 2006. Fotossensibilização hepatógena em equinos pela ingestão de Brachiaria humidicola (Graminae) no Estado do Pará. Pesq. Vet. Bras. 26(3):147-153. <https://dx.doi. org/10.1590/S0100-736X2006000300003>

Brum K.B., Haraguchi M., Garutti M.B., Nóbrega F.N., Rosa B. \& Fioravanti M.C.S. 2009. Steroidal saponin concentrations in Brachiaria decumbens and $B$. Brizantha at different developmental stages. Ciência Rural 39(1):279-281. <https://dx.doi.org/10.1590/S0103-84782008005000034>

Brum K.B., Haraguchi M., Lemos R.A.A., Riet-Correa F. \& Fioravanti M.C.S. 2007. Crystal-associated cholangiopathy in sheep grazing Brachiaria decumbens containing the saponin protodioscin. Pesq. Vet. Bras. 27(1):39-42.<https:// dx.doi.org/10.1590/S0100-736X2007000100007>

Caicedo J.A., Ospina J.C., Chaves C.A., Peña J., Lozano M.C. \& Doncel B. 2012. Hepatic lesions in cattle grazing on Brachiaria decumbens in Mesatas, Meta (Colombia). Revta Med. Vet. Zootec. 59(2):102-108.

Castro M.B., Gracindo C.V., Landi M.F.A., Cabral Filho S.L.S., Resende Filho N.J., Lima E.M.M. \& Riet-Correa F. 2018. Sheep adaptation management, and investigation of inherited resistance to prevent Brachiaria spp. poisoning. Small Rumin. Res. 158:42-47. <https://dx.doi.org/10.1016/j. smallrumres.2017.12.001>

Castro M.B., Santos Jr. H.L., Mustafa V.S., Gracindo C.V., Moscardini A.C.R., Louvandini H., Paludo G.R., Borges J.R.J., Haraguchi M., Ferreira M.B. \& RietCorrea F. 2011. Brachiaria spp. poisoning in sheep in Brazil: experimental and epidemiological findings, p.110-117. In: Riet-Correa F., Pfister J., Schild A.L. \& Wierenga T. (Eds), Poisoning by Plants, Mycotoxins and Related Toxins. CAB International, London.

Collett M.G. 2019. Photosensitisation diseases of animals: classification and a weight of evidence approach to primary causes. Toxicon X. 3:100012. <https://dx.doi.org/10.1016/j.toxcx.2019.100012><PMid:32550569>

Cook C.W. 1964. Collecting forage samples representative of ingested material of grazing animals for nutritional studies. Anim. Sci. J. 23(1):265-270. <https://dx.doi.org/10.2527/jas1964.231265x>

Cruz C., Driemeier D., Pires V.S. \& Schenkel E.P. 2001. Experimentally induced cholangiopathy by dosing sheep with fractionated extracts from Brachiaria decumbens. J. Vet. Diag. Invest. 13(2):170-172. <https://dx.doi. org/10.1177/104063870101300215 > <PMid:11289217>

De Oliveira C.H.S., Barbosa J.D., Oliveira C.M.C., Bastianetto E., Melo M.M., Haraguchi M., Freitas L.G.L., Silva M.X. \& Leite R.C. 2013. Hepatic photosensitization in buffaloes intoxicated by Brachiaria decumbens in Minas Gerais state, Brazil. Toxicon 73:121-129. <https://dx.doi.org/10.1016/j. toxicon.2013.07.001><PMid:23850427>

Diamantino G.M.L., Biscoto G.L., Pedroza H.P., Amorim R.N.L., Keller K.M., Melo M.M. \& Soto-Blanco B. 2018. Liquid chromatography coupled to quadrupole time-of-flight- mass spectrometry (QTOF/MS) assay for quantification of protodioscina in Brachiaria grasses. Toxicon 155:61-65. <https://dx.doi. org/10.1016/j.toxicon.2018.10.008>
Diamantino G.M.L., Pierezan P., Ferreira M.I.C., Rocha W.S.D., Veiga V.M.O., Martins C.E., Veiga M.O. \& Soto-Blanco B. 2020. Photosensitization by Brachiaria ruziziensis in a sheep herd. Toxicon 185:1-4. <https://dx.doi. org/10.1016/j.toxicon.2020.06.022>

Driemeier D., Colodel E.M., Seitz A.L., Barros S.S. \& Cruz C.E.F. 2002 Study of experimentally induced lesions in sheep by grazing Brachiaria decumbens. Toxicon 40(7):1027-1031. <https://dx.doi.org/10.1016/ s0041-0101(01)00276-8><PMid:12076657>

Faccin T.C., Riet-Correa F., Rodrigues F.S., Santos A.C., Melo G.K.A., Silva J.A., Ferreira R., Ítavo C.C.B.F. \& Lemos R.A.A. 2014. Poisoning by Brachiaria brizantha in flocks of naïve and experienced sheep. Toxicon 82:1-8. <https://dx.doi.org/10.1016/j.toxicon.2014.02.008><PMid:24561120>

Ferreira M.B., Brum K.B., Fernandes C.E., Martins C.F., Pinto G.S., Castro V.S., Rezende K.G., Riet-Correa F., Haraguchi M., Wysocki H.L. \& Lemos R.A.A. 2011. Variation in saponin concentration in Brachiaria brizantha leaves as a function of maturation: preliminar data, p.118-123. In: Riet-Correa F, Pfister J., Schild A.L. \& Wierenga T.L. (Eds), Poisoning by Plants, Mycotoxins and Related Toxins. CAB International, Wallingford.

Gracindo C.V., Louvandini H., Riet-Correa F., Barbosa-Ferreira M. \& Castro M.B. 2014. Performance of sheep grazing in pastures of Brachiaria decumbens, Brachiaria brizantha, Panicum maximum, and Andropogon gayanus with different protodioscin concentrations. Trop. Anim. Health Prod. 46(5):733737. <https://dx.doi.org/10.1007/s11250-014-0556-y ><PMid:24557590>

INMET 2018. Instituto Nacional de Meteorologia, Ministério da Agricultura Pecuária e Abastecimento. Available at <www.agraer.ms.gov.br/cemtec > Accessed on Jun. 2018.

Lee S.T., Mitchell R.B., Wang Z., Heiss C., Gardner D.R. \& Azadi P. 2009. Isolation, characaterization, and quantification of steroidal saponins in switchgrass (Panicum Virgatum L.). J. Agric. Food. Chem. 57(6):2599-2604. <https:// dx.doi.org/10.1021/jf803907y > <PMid:19243100>

Lelis D.L., Rennó L.N., Chizzotti M.L., Pereira C.E.R., Silva J.C.P., Moreira L.G.T., Carvalho F.B.P. \& Chizzotti F.H.M. 2018. Photosensitization in naïve sheep grazing signal grass (Brachiaria decumbens) under full sunlight or a silvopastoral system. Small Rumin. Res. 169:24-28. <https://dx.doi. org/10.1016/j.smallrumres.2018.08.018>

Lemos R.A.A., Ferreira L.C.L., Silva S.M., Nakazato L. \& Salvador S.C. 1996. Fotossensibilização e colangiopatia associada a cristais em ovinos em pastagem com Brachiaria decumbens. Ciência Rural 26(1):109-113. <https://dx.doi.org/10.1590/S0103-84781996000100020>

Lima F.G.D., Haraguchi M., Pifster J.A., Guimarães V.Y., Andrade D.F., Ribeiro C.S., Costa G.L., Araujo A.L.L. \& Fioravanti M.C.S. 2012. Weather and plant age affect the levels of steroidal saponin and Pithomyces chartarum spores in Brachiaria grass. Int. J. Poisonous Plant Res. 2:45-53.

Low S.G. 2015. Signal grass (Brachiaria decumbens) toxicity in grazing ruminants. Agriculture 5:971-990.<https://dx.doi.org/10.3390/agriculture5040971>

Lozano M., Martinez N. \& Diaz G. 2017. Content of the saponin protodioscin in Brachiaria spp. from the Eastern Plains of Colombia. Toxins 9(7):220. <https://dx.doi.org/10.3390/toxins9070220><PMid:28703748>

Melo G.K.A., Ítavo C.C.B.F., Silva J.A., Monteiro K.L.S., Faccin T.C., Pupin R.C., Heckler R.F., Ítavo L.C.V., Silva P.C.G., Leal P.V. \& Lemos R.A.A. 2018. Poisoning by Brachiaria spp. in suckling lambs supplemented and unsupplemented in a creep-feeding system. Small Rumin. Res. 158:30-34. <https://dx.doi. org/10.1016/j.smallrumres.2017.11.014>

Melo G.K.A., Silva W.J., Pupin R.C., Heckler R.F., Nonato L.M., Ítavo C.C.B.F., Ferreira V.B.N. \& Lemos R.A.A. 2019a. Comparison of two collection methods to determine protodioscin concentrations in Brachiaria spp. and to monitor Brachiaria spp. poisoning. Pesq. Vet. Bras. 39(9):710-714.<https://dx.doi. org/10.1590/1678-5150-PVB-6226>

Melo G.K.A., Silva W.J., Pupin R.C., Heckler R.F., Nonato L.M., Ítavo C.C.B.F., Ferreira V.B.N. \& Lemos R.A.A. 2019b. Poisoning by Brachiaria spp. In various lamb breeds at increasing levels of supplementation during growth. Pesq. Vet. Bras. 39(12):978-982. <https://dx.doi.org/10.1590/16785150-PVB-6478> 
Muniandy K.V., Teik Chung E.L., Jaapar M.S., Mohd Hamdan M.H., Salleh A. \& Abdullah Jesse F.F. 2020. Filling the gap of Brachiaria decumbens (signal grass) research on clinico-pathology and haemato-biochemistry in small ruminants: a review. Toxicon 174:26-31. <https://dx.doi.org/10.1016/j. toxicon.2019.12.158>

Mustafa V.S., Moscardini A.R.C., Borges J.R.J., Reckziegel G.C., Riet-Correa F. \& Castro M.B. 2012. Intoxicação natural por Brachiaria spp. em ovinos no Brasil Central. Pesq. Vet. Bras. 32(12):1272-1280. <https://dx.doi. org/10.1590/S0100-736X2012001200010>

Ogliari D., Molossi F.A., Savaris T., Wicpolt N.S., Zacan I. \& Gava A. 2018. Intoxicação espontânea por Brachiaria híbrida cv mulato I em ovinos e caprinos e experimental por Brachiaria híbrida cv mulato II em ovinos. Pesq. Vet. Bras. 38(2):229-233. <https://dx.doi.org/10.1590/1678-5150-PVB-4747>

Porto M.R., Saturnino K.C., Lima E.M.M., Lee S.T., Lemos R.A.A., MarcolongoPereira C., Riet-Correa F. \& Castro M.B. 2013. Avaliação da exposição solar na intoxicação experimental por Brachiaria decumbens em ovinos. Pesq. Vet. Bras. 33(8):1009-1015. <https://dx.doi.org/10.1590/S0100736X2013000800011>

Pupin R.C., Melo G.K.A., Heckler R.F., Faccin T.C., Ítavo C.C.B.F., Fernandes C.E.C., Gomes D.C. \& Lemos R.A.A. 2016. Identification of lamb flocks susceptible and resistant against Brachiaria poisoning. Pesq. Vet. Bras. 36(5):383-388. <https://dx.doi.org/10.1590/S0100-736X2016000500005>
Riet-Correa B., Castro M.B., Lemos R.A.A., Riet-Correa G., Mustafa V. \& Riet-Correa F. 2011. Brachiaria spp. poisoning of ruminants in Brazil. Pesq. Vet. Bras. 31(3):183-192. <https://dx.doi.org/10.1590/S0100736X2011000300001>

Rosa F.B., Rubin M.I.B., Martins T.B., Lemos R.A.A., Gomes D.C., Pupin R.C., Lima S.C. \& Barros C.S.L. 2016. Spontaneous poisoning by Brachiaria decumbens in goats. Pesq. Vet. Bras. 36(5):389-396. <https://dx.doi.org/10.1590/ S0100-736X2016000500006>

Saturnino K.C., Mariani T.M., Barbosa-Ferreira M., Brum K.B., Fernandes C.E.S. \& Lemos R.A.A. 2010. Intoxicação experimental por Brachiaria decumbens em ovinos confinados. Pesq. Vet. Bras. 30(3):195-202. <https://dx.doi. org/10.1590/S0100-736X2010000300002>

Souza R.I.C., Riet-Correa F., Brum K.B., Fernandes C.E., Barbosa-Ferreira M. \& Lemos R.A.A. 2010. Intoxicação por Brachiaria spp. em bovinos no Mato Grosso do Sul. Pesq. Vet. Bras. 30(12):1036-1042. <https://dx.doi. org/10.1590/S0100-736X2010001200006>

Utiumi K.U., Albuquerque A.S., Burque A.S., Souza F.R., Sonne L., Varaschin M.S., Raymundo D.L. \& Peconick A.P. 2018. Experimental poisoning by Brachiaria decumbens in rabbits. Pesq. Vet. Bras. 38(10):1885-1889. <https://dx.doi.org/10.1590/1678-5150-PVB-5599> 